\title{
Financial Challenges of Small and Medium-Sized Enterprises (Smes) In Nigeria: The Relevance of Accounting Information
}

\section{Ohachosim Celestine Ikem,}

Dept. of Accountancy,

Faculty of Business Administration,

University of Nigeria,

Enugu Campus, Enugu State.

Onwuchekwa Faith Chidi,

Department of Business Administration,

Nnamdi Azikiwe University,

Awka, Anambra State.

\section{Ifeanyi Toochukwu Titus,}

Dept. of Accounting,

Federal college of Education (tech),

Umunze, Anambra State.

\begin{abstract}
The relevance of SME-sub sector in Nigeria's economy has necessitated the need for empirical investigations into the nature of its financial challenges. This paper evaluates the extent accounting information can be used to ameliorate the financial challenges of SMEs in Nigeria. It explored both theoretical and empirical literatures as bases for the study. It made use of questionnaire for collecting data from a sample of SMEs in Nigeria. Tables and graphs describe the responses for better understanding. By the technique of Ordinary Least Square (OLS), the researchers analysed the group logit (GLOGIT) model specified in the paper. Our analyses reveal that SMEs in Nigeria have poor accounting system. It was also found that SMEs' access to finance depends largely on the quality of accounting information they can generate which is determined by their accounting practices. The paper recommends that SMEs should access the services of the accountant to be able to establish dependable accounting system which is characterised by generally accepted accounting practices (GAAPs). Quality accounting information will enhance SMEs' financial management as well as accessibility of finances.
\end{abstract}




\section{Introduction}

Small and Medium-scale Enterprises (SMEs) play very important roles in the process of industrialization and sustainable economic growth (Ogujiuba, Ohuche and Adenuga, 2004; Ariyo, 2005; Ihua, 2009; Aremu and Adeyemi, 2011; Terungwa, 2012). Since the 1960s to date, (SMEs) are being given due recognitions especially in the developed nations for playing very important roles towards fostering accelerated economic growth, development and stability within several economies (Gunu, 2004; Onugu, 2005; Aremu, 2010). They make-up the largest proportion of business all over the world and play tremendous roles in employment generation, provision of goods and services, creating a better standard of living, as well as immensely contributing to the Gross Domestic Products (GDP) of many countries (Ihua,2009;Paul,2010;Ojeka and Mukoro,2011). In the United States of America, SMEs employ 50\% of her workforce, and generate more than half of the nation's Gross Domestic Products (Audretsch, 2010). SMEs account for $99.8 \%$ of all companies and $65 \%$ of business turnover in European Union (Ariyo, 2005). The situation is not different in Africa as research reported by Kongolo (2010) reveals that in South Africa, SMEs account for about $91 \%$ of the formal business entities contributing about $51 \%$ and $57 \%$ of GDP, providing almost $60 \%$ of employment.

SMEs sub-sector came into the mainframe of policy formulation in Nigeria owing to its obvious vital contributions (Obamuyi, 2007). Like in the developed countries, SMEs have enabled entrepreneurship activities through which employments have been generated and poverty reduction and sustainable livelihood achieved (Ogujiuba et al, 2004). It makes up about $97 \%$ of businesses in Nigeria and provide on average $50 \%$ of Nigeria's employment, and its industrial output (Ariyo, 2005; Taiwo, Ayodeji and Yusuf, 2012). SMEs have the ability to start small and grow quickly and as well survive through rapid response adjustment in good and bad economic times (Mitchell and Raid,2000; Nandan,2010). Government and development experts have, therefore, realised the fact that SMEs possess the needed catalyst to turn the economy around for good (Udechukwu, 2003; Anyanwu, 2003) 
However, for SMEs to perform the roles as enumerated above, they need adequate funding in terms of short and long-term loans. Due to the nature of SMEs, funds are always in short supply to them (Srinivas, 2005). It then became necessary that SMEs should be assisted largely by public initiative involving participation of the banking industry (Srinivas, 2005). Government of Nigeria has made elaborate effort to assist the SMEs in their funding problems (Anyanwu, 2003; Terungwa, 2012). According to Olorunshola (2003) the government has been active in the development of SMEs in Nigeria in the following areas;

* Funding and setting up industrial areas and estates (to reduce overhead costs)

* Providing local finance through its agencies: the Central Bank of Nigeria, Federal Ministry of Industries (Small-Scale Industry Credit Scheme SSICS), Nigeria Industrial Development Bank (NIDB), and Nigeria Bank for Commerce and Industry (NBIC).

* Facilitating and guaranteeing external finance through the World Bank, African Development Bank and other international institutions willing to and capable of assisting SMEs.

* Facilitating the establishment of the National Directorate of Employment (NDE) which also initiates the setting up of New SMEs.

* Setting up of the erstwhile National Economic Reconstruction Fund (NERFUND) which is a source of medium to long-term local and foreign loans for small and medium scale business, particularly those located in the rural areas.

* Initiating the then Family Economic Advancement Programme (FEAP); and

* Provision of technical training and advisory assistance programmes through establishment of industrial development centres, etc.

Ogujiuba et al (2004) pointed out that in the bid to enhance the development of SME, that government has established several microlending institutions. The government has tried to achieve the above assistance to SMEs through the following agencies and schemes.

* The Nigeria Industrial Development Bank Ltd (NIDB) (1962)

* The Nigeria bank for Commerce and Industry (NBCI) (1973)

* Rural Banking Scheme (1977) 


$\begin{array}{ll}* & \text { Agricultural Credit Guarantee Scheme fund (1978) } \\ * & \text { Word Bank Assisted SME Loan Project (1987) } \\ * & \text { Peoples Bank of Nigeria (1989) } \\ * & \text { The National Economic Reconstruction fund (NERFUND) } \\ & (1990) \\ * & \text { Community Bank (1991) } \\ * & \text { Nigeria Export Import Bank (1991) } \\ * & \text { The bank of Industry (2000) } \\ * & \text { Nigeria Agricultural, Corporative and Rural Development bank } \\ & \text { (NACRDB) (2000) } \\ * & \text { The Small and Medium Industries Equity Investment Scheme } \\ & \text { (SMIEIS) (2001) } \\ * & \text { Refining and Rediscounting Facilities (2002) } \\ \text { Microfinance Banking (2005) }\end{array}$

Despite all the efforts of government, progress of SMEs in Nigeria is still limited due to financial challenges (Ohachosim, 2012). It can be logically correct to conclude from the above that the financial challenges of SMEs in Nigeria today, have taken the dimension of inaccessibility of funds (Aremu and Adeyemi, 2011). Obstacles of SMEs access to funds in Nigeria have not been surmounted because of SMEs inability to generate and use quality accounting information (Richard, McMahon and Holmes, 1991). In the face of poor accounting or non-existence accounting information, good funds management is inhibited. Once the SME commences business operations the nature of its fund management is reflected in the new establishment. Suppose the fund management is inadequate, it will be difficult for the new business to attract additional funds for increased working capital, expansion or diversification. It is based on this reasoning that very crucial and onerous tasks are set before the accountant who is equipped with the skills and theories of business to produce accounting information. It is exigent that financial challenges of SMEs be given passionate attention by business professionals especially the accountant. SMEs financial challenges really entail extensive and constant efforts on the part of the accountant to assist owner-managers to access adequate finances at affordable costs: "A good accountant is the most important outside advisor the small business owner has" (Cornish, 1993). According to 
the Entrepreneur Magazine Small Business Advisor, “ The services of a Lawyer and other business consultants are vital during specific periods in the development of a small business or in times of trouble, but it is the accountant who, on a continuing basis, has the greatest impact on the business"(Encyclopaedia of Business, 2010). The onerous tasks before the accountant does not get accomplished only by producing adequate accounting information, it proceeded to include all processes to awaken the consciousness of the SME-owners to the proper uses of the information to arrest their financial challenges (Watson, 2003). Available studies on the financial challenges of SMEs in Nigeria did not attempt to find out whether SMEs' access to finances is dependent on their accounting practices. This work is justified because it has holistic focus (availability, accessibility and management of funds) on the financial challenges of SMEs with respect to the roles of the accountant to overcome these challenges.

It is unfortunate that SMEs performances have fallen short of expectations in Nigeria (Osotimehin, 2012). The country is still characterised with alarming unemployment rate of $19.7 \%$ in 2010 (CIA, 2010), as well as, high level of poverty for more than half of the population still live below the poverty line (Abu and Abdullah, 2010). This shows that Small and Medium- Scale Enterprises are not very effective in this part of the world. Most SMEs die shortly after their establishment and few that survive die following the ageing or physical incapacitation or death of their owners. The failure rate of small business stands around 50 percent in Africa (Adelakun, 2008; Ebiringa, 2011). Huyghebaert and Gucht (2004) have noted that 50\% of new entrepreneurial ventures disappear within the first five years after their establishment in USA and probably that of Nigeria is higher. It should be noted that most business failures result in heavy personal loss for the entrepreneur (Bannock, 1980; Watson, 2003). The country also count losses; the loss in taxation and the business contribution to gross domestic product (GDP) as well as employment, add up to very huge losses for the country as a whole.

The circumstances highlighted above have persisted due to poor generation and use of accounting information in Nigeria. The absence 
of basic accounting practices in most SMEs in Nigeria tends to compound their financial challenges. Most SMEs can't access funds because banks and other financiers cannot readily verify their vibrancy and their access to quality projects (Srinivas, 2005). Stigliz and Weiss (1981) expressed the view that small and medium scale firms with opportunities to invest in positive net present value project may be blocked from doing so because of adverse selection and moral hazard problems. Such discriminations arise because the SMEs don't have comprehensive accounting records to be utilized in proper project evaluation and budgeting. In relation to the above are improper investments in both current and fixed assets. SMEs sometimes tie huge capital where it is simply not needed. Inventories can be excessively stocked and more credit facility than necessary extended to customers amidst insufficient funds to meet up with its working capital requirements, such as; meeting up with obligations as it falls due, payment of workers, paying on terms of agreement to suppliers, among others. The situation is the same on the side of investment in fixed assets. A close look in the Nigeria business scene will observe that some investments in fixed assets really don't yield the much returns commensurate to its capital outlay and some don't even yield at all. Some investments remain under construction for years and in fact many don't ever reach completion stage. There are many investments that got completed but never become operative. Fixed assets are used until they become physically inefficient due to long years of usage; and because there is no adequate provision for depreciation, replacement is often difficult. The situation is prominent in agro and agro-based businesses, petroleum service stations and manufacturing ventures. Most often SME can't determine with certainty what their average yearly profits are. This has always led to excessive drawings. A good number of business (SMEs) has failed in Nigeria because the owners have overdrawn more money than the profit made by the business in many unaccounted occasions. It will then imply that the SME-operator was eroding the capital of the business without knowing it. The consequence of capital erosion is fund evaporation. Of course, the capital of the business will see to be vanishing because the SME-owners often can't give account of what happened to the capital of the business. 
With reference to the problem highlighted above, this study has the following objectives: to determine the accounting practices of SMEs in Nigeria and to determine the extent at which SMEs' access to finance is dependant on their accounting practices in Nigeria. In order to achieve the above stated objectives, this study has asked the following questions: how adequate are the accounting practices of SMEs in Nigeria and to what extent does the SMEs' access to finances depend on their accounting practices in Nigeria? The hypotheses relevant for this study are: SMEs in Nigeria do not have poor accounting practices and SMEs' access to finance in Nigeria does not depend on their accounting practices.

\section{Literature Review}

Recently, banks practices all over the world have shown that accounting information has provided bases for evaluating SMEs for the purpose of making funds accessible to them (Ohachosim, 2012). These contemporary banks practices have given rise to certain models/rules such as; Bank capital channel model, Bank capital constraint model of lending behaviour, financial statement rule, Asset Based Rule, Credit Scoring and Relationship lending. Some of these models/rules emerged because of the unique nature of SMEs which has made it difficult for their viability to be evaluated on the bases of the known feasibility reports. By definition in Nigeria, Small and Medium Industries Equity Investment Scheme (SMIEIS), defined SMEs as those enterprises with a total capital employed not less than N1.5million, but not exceeding N200million, including working capital, but exceeding cost of land and/or with a staff strength of not less than 10 and not more than 300 (Obamuyi, 2007). This definition has included many small firms under the bin shade of SMEs. The nature of business transactions in most of these firms does not provide opportunities for outsiders to have clear knowledge of the goings-on in these small firms. This is what is prominently referred to as information asymmetries. It is because of this that assessment of the viability of projects in small firms demand processes more reliable than mere feasibility reports. The methods in use so far rely heavily on accounting information thus revealing to the accountants the tasks ahead to serve the accounting need of the SMEs today. 
Accounting information has also been found to be very crucial for the purpose of financial management. Empirically, it has been demonstrated by a number of studies that the accountant possesses the skill with which any meaningful financial management can be instituted in any organization (Brean, Scuilli \& Calvet: 2003). Studies have also shown that sound financial management is crucial to survival and growth of small business (Gorton: 1999). The fact that high rate of small business failure is attributed to poor or careless financial management has lain itself to empirical evidence. Effective financial management can only be instituted in the presence of quality accounting information. Potts (1977) states that the clearest and most startling distinction between successful and discontinued small businesses lie in their approach to uses which can be made of accounting information. Accounting information is not a mere fabrication of the accountant; it is actually the results of business undertakings of the SMEs. This would mean that the accountant should be aware of the business activities and ensure that relevant ingredients are not dropped on the way. This work would, therefore, review empirical literature on the practices of some successful SMEs with the aim of finding out what has ensured their financial breakthrough.

DeThomas and Fredenberger (1985) carried out a survey of some progressive 360 SMEs in Georgia and find out that they have installed and used very effective accounting information systems. The survey reveals that the SMEs have high standard of financial recordkeeping. Around 92 percent of respondents had some form of recordkeeping beyond check stub deposit receipts. It is quite obvious that the success of the SMEs studied is attributed to their accounting systems which were very effective in line with this, is the finding of D'Ambose and Gasse (1980) who studied the utilization of formal management techniques in 25 small shoe manufacturers and 26 small manufacturers in plastics industry in Quebec Canada and found that a cost accounting system was in operation in about 88 percent of businesses studied. Richard et al (1991) explained that the availability of affordable computers and suitable software has played an important part in promoting a working accounting system. Magnenat-Thalmann (1982) discovered a preponderance of accounting related applications among 
computer software use; particularly in the areas of accounts receivable, payroll accounts payable, general ledger, sales analysis and inventory. Good and working accounting systems make judicious uses of computer and applicable computer-softwares. DeThomes and Fredenger (1985) and Nickell and Seado (1986) confirm that accounting/financial management application dominate as computer applications in small businesses examined.

It is briefly highlighted at the introductory part of this review that improved accounting information systems enhance the quality of financial reporting. Richard et al (1991) opines that improved accounting systems due to uprising in computerising accounting systems following innovations in manufacturing affordable computers in recent times has elevated the standard of financial reporting in small businesses in North America. Consequent upon the installation and use of an accounting information system, satisfactory aggregation of the business activities is achieved in forms of records. This has enhanced financial reporting. DeThomas and Frederberger (1985) found that 81 percent of the small businesses in their survey produced financial statements in the forms of balance sheet, income statements, and fund statements, among others. There are others who include in their financial reports, the cash flow summary, others operating summaries and bank reconciliation statements. There are more obvious evidences that adequate accounting information system enhances the regularity of financial reporting. Thomas and Evanson (1987) found among a study of 398 small pharmacies located in the states of Michigan, North Carolina, Nebraska Rhode Island and Washington that income statements and Balance Sheets were prepared al least quarterly by 62.5 percent of the respondent and annually by 32.1 percent. Thomas and Evanson (1987) reported that over 85percent of the respondents indicated that an outside accountant prepared the financial statements $f$ on their behalf. This is further evidence that good accounting systems prepare the grounds for effective financial reporting.

It is obvious that the quality of accounting information has improved as depicted in the review above but empirical evidence shows that the use of this information is still limited. Richard at al (1991) noted that in 
contrast to the amount of information available, the actual use made of financial reports by owner-managers is rather limited. Evidence provided by Lindecamp (1983) in the United States of America on the analysis and use of financial statement of 102 owner-managers of retail stores in Mississippi supports the assertion. About 23 percent reported that they analysed a detailed breakdown of their figures on a frequent or regular basis. However, 60percent indicated that they do not maintain up-to-date figures on the contribution to profit of individual products or product lines. A little 7 percent seldom or never compared their firm's performance with industry figures. Over 50 percent of respondents did not appear to understand the meaning of debt/equity ratio, and 59 percent did not know the value of this ratio for their firm. Also, DeThomas and Fredenberger (1986) reported in their survey that only 11 percent of the respondents use financial statement information as part of their normal process of managerial evaluation, planning and decision-making, although 61 percent of the respondents felt the statements provided the information they required for planning and decision-making. Only a small proportion of businesses ( 2 percent) employed financial ratio analysis and few made mere simple historical comparisons. Even though it was not possible to demonstrate a significant association between the number and frequency of use of financial rates and small business profitability or survival, it is hypothesized that this may have been due to a lack of sophistication in financial ratio interrelation on the part of owner-mangers which prevented usage from making a discernible difference (Thomas and Evanson, 1987).

It is also noted that small businesses have very poor working capital management traditions. A study of small businesses in Northern America, show that they have no formal techniques of determining the level of cash balances (Anvari and Gopal, 1983). This would mean that there are chances of SMEs keeping more cash than they actually required or otherwise. Also, Grablowsky and Rowell (1980) in a survey found that small businesses have poor credit management. In fact, they explained that they see accounts receivable as something that is exogenously controlled. Only few small businesses among those who are included in the survey employed credit officer. In the same way 
Grablowsky $(1978,1984)$ obtained enough empirical evidence to affirm that small businesses do not view accounts payable as a source of finances for their businesses. They only accept cash discounts when it is available and do not make effort to compare the cost taking advantage of cash discount with the cash discount itself with regards to their cost of capital. Grablowsky (1984) further concludes that small businesses rarely use formal techniques for inventory management. For instance, they have poor habit of using quantitative techniques like economic order quantity. The fact is that most SMEs accounting systems were not able to provide information on inventory turnover, reorder points, ordering costs or carrying costs. The capital budgeting practices of small businesses is also very low. Grablowsky and Burn (1980) found that the level of understanding and use of more advanced capital budgeting policies and techniques were low. Richard et al (1991) explained that approval for capital budgeting in SMEs are simply based on necessity, this is contrary to large firms who have yearly annual capital budgets.

Generally empirical evidences available in literature from advance countries reveal that SMEs' use of accounting information is very poor. However, due to improved accounting systems owing to the increase in the use of computers and software applications, the quality of accounting information has improved tremendously.

Mamahon \& Holmes (1991) expressed the view that the SMEs should be encouraged to use software accounting package as it enhances the accounting discipline. This is evident in the study undertaken by Gorton (1991). In the study, a comparative UK study of SMEs that used financial management techniques and those that didn't found that out of 366 SME respondents who use financial plan that over two -thirds maintained a Computerized Accounting System (CAS). On this Gorton (1991) quantified the importance of planned financial management through the setting of financial plans and the maintenance of comprehensive accounting systems. There is, therefore, a relationship between the use of CAS and strategic orientation (Gorton: 1999; Smith, 1999). The use of CAS instils controls in the SMEs. McMahon (2001) argued that improved financial control in growing SMEs can and should 
come about through a significant upgrading of financial reporting system. This view is supported by Hans and Valeri (2010) who reported in their research that when accounting information is a good description of credit risk firms can rely on performance covenants which creates access to debt financing. Their research also proved that when accounting information is poor description of credit firms resort to the more robust capital covenants which align incentive by restricting debt financing and therefore limit credit market access. It is conclusive, therefore, that accounting-based covenants create market access through the use of performance covenants.

On the relevance of the accountant to SMEs, Association of Certified Chartered Accountants (ACCA) has carried out a number of researches to empirically investigate the particular circumstances where the accountants are really relevant. *ACCA research report No.18, which indicates the potential role of the profession in supporting small business (Chittenden, McConnel and Risner, 1990).

*ACCA research report No.64, which highlights the role of accountants in assisting with networks providing advice on business performance and ensuring learning takes place for SMEs, particularly at the early stages of the business life-cycle(Deakins, Logan and Steele, 2001).

*ACCA research report No.85, which points that ageing populations herald a need to provide for succession planning services(Martin,2005). ACCA research report No.70 share perceptions from both small practitioners and SMEs about e-commerce. It is of particular interest that SMEs do not perceive that accountant could assist them beyond very basic functions (Chaston and Mangels, 2001).

*ACCA research report No.71 isolates the minority ethnic respondents' comments and illustrates how small practitioners might expand their fee base (Ram and Carter, 2001).

*ACCA research report No. 96 finds that accountants are key advisers on regulation to all businesses, and are in the position to assist SMEs in managing their regulator obligation (Blackburn et al, 2006). The study 
is largely presented from the perspective of the SMEs in the UK and Canada and contains extensive data on the use they have made of accountants

*ACCA research report No. 99 surveys both accounting practitioners and SMEs in Australia to understand how accountants help SMEs with their regulatory obligations and finds that accountants are willing to assist or refer their clients to specialist advisers. Although the service given by accountants was deemed to be very good, the issue of value for money was raised (Leung, Raar and Tangey 2008).

Still on relevance of the accountants' advice, researches are in accords that accountants' advices prove useful. However, there is disaccord as to the effects of their advices on the business. Accountants are of the most-used professional support providers (Atkinson and Hurstifield, 2003; Jay and Scheper, 2003). It is surprising that Accountants' advices are not related to any of the performance measures (Jay and Scheper, 2003).

Breen, Wilmshurst, and Calvert (2003) believe that the external accountant can solve variety of small business challenges including choice of software. The pre-occupation in companies work is reduced by the standardization of the accounting system through the use of computers and accounting soft wares.

Obamuyi (2007) in the paper titled "An exploratory study of loan delinquency among small and medium enterprises (SME) in Ondo State of Nigeria" maintained that the lending practices towards SMEs are not different from those for large enterprises. It is because of this that makes it difficult for SMEs to meet the criteria for accessing bank loan .The paper went further to state some standard criteria to assess the creditworthiness of borrowers as follows; financial strength, profitability, network, track record, management quality, relations and payment records with other banks, business prospects, business risks and collateral securities. All the above criteria cannot be good assessments without adequate accounting. It is because of the deficiency in the record keeping of SME that compels the banks to insist on 
collateral as a "must" for SME. As Obamuyi (2007) has put it, "The banks requested for collateral as an additional requirement, apart from requiring personal guarantees for SME loans, because the financial and operational transparencies of SMEs were relatively low and their accounting standards were poor"

Ojeka \& Mukoro (2011) in the topic titled, "International Financial Reporting Standard (IFRS) and SMEs in Nigeria: Perception of Academic" found that there is still need to enlighten people especially the SME operators on the usefulness of the IFRS for SMEs. The accountant will really have a lot of work to do to implement the IFRS for SMEs in Nigeria. The listed advantages of IFRS for SMEs includes; improving the comparability of information presented in financial statement, increasing confidence in global annual invoices, SMEs reduce cost associated with maintaining accounting standards, presence of a complete set of accounting principles simplified for each type of entity; increased satisfaction of the needs of users of financial statements (AICPA, 2011; Marion, 2009). Ojeka \& Mukoro (2011) empirically demonstrated that the IFRS for SMEs will help to gain more capital for growth and expansion. This is because such standard will attract investors and the fact that some banks like; GTB Bank, Access Bank, Zenith and First Bank, have embraced the IFRS for SMEs is an evidence to the assertion (Naomi, 2010; Ojeka and Mukoro, 2011)

The fact that the SME owners are amateur in business management creates varieties of opportunities for external services providers like the accountant (Yusoff, 2006). Empirical evidence suggests that accountants play a key role in advising SMEs, because they provide the most frequent source of advice (Benneth and Smith, 2002; Carter and Mason, 2006; Scoth and Irwin, 2009; Devi and Samujh, 2010), especially in matters relating to regulation and compliance (Gooderham et al 2004; Blackburn et al 2006; Leung et al, 2008). Following the changing of global business environment, the accountants' services to SMEs have changed from mere regulation and compliance work (Chaston et al, 2002). CPA Australia (2007) points out that service and product mixes will change and that public practitioners will need to review their levels of knowledge, and training, and then management 
strategies in order to meet the demand for business advisory services. Devi \& Smith (2010) concluded that due to the fact that accountants have not noticed the need for them to acquire peculiar mindset towards the SMEs that Accountant are not used as supposed by the SMEs. It is, therefore, reasonable for the accountant to prepare for the emerging tasks. There is need to increase time with the SME and also there is need to bring down the level of interaction to be compatible with the level of SME- operators.

\section{Methodology}

This research made use of primary data. This was obtained from a sample of SME-operators in Nigeria. The population for the study has been restricted to the number of SMEs in Anambra state due to proximity and cost. The population for the study is two thousand six hundred and eight-eight (2688) SMEs being the figure obtained from the latest survey of the Ministry of Commerce and Industry, Anambra state (Ministry of Commerce and Industry, 2009). The research made extensive use of questionnaires which were fully structured. A total of three hundred and forty eight questionnaires were distributed adopting the stratified random sampling technique. The sample size of 348 was obtained using the Taro Yamene's formula. The test-retest method was adopted to ensure the reliability of the data collection process. Econometric method, specifically the group logit model (GLOGIT) was adopted. Ordinary Least Square (OLS) technique was used for the purpose of analysing the GLOGIT model. This technique was considered suitable because the model of this research was based on the theories of qualitative response regression models. Amemiya (1981), Aldrich (1984), Larry (1997) and Moghaddan and Hallie (2009) have used the quality response regression models to achieve dependable results. Data is weighted to correct for hetroscedasticity (Gujarati, 2009).

The model adopted in this research for econometric analyses is specified as follows: 
Access to Credit is a function of the availability of quality accounting information. Quality accounting information is a function of the level of accounting practice.

Therefore, it follows that access to credit is a function of the level of accounting practice. Other variables also determine credit accessibility: this is captured by introducing another variable in the model as the availability of collateral facility. The model can be represented as follows;

Access to Credit $=\mathrm{f}$ (level of accounting practice and collateral facility) Through the cumulative logistic distribution function, this is translated into the Group Logit model (Glogit)

Thus,
$\mathrm{L}_{1}=\mathrm{In}=\beta_{1}+\left(\begin{array}{c}\mathrm{P}_{1} \\ \frac{\beta_{2} \mathrm{X}_{1}}{1-\mathrm{P}_{1}}\end{array}\right)+\beta_{3} \mathrm{X}_{2}+\mu_{1}$
In the Glogit model adopted above

In the Glogit model adopted above,

$\mathrm{P}_{1=}$ ni

$\mathrm{N}_{\mathrm{i}}$ (which represents the probability of accessing credit at ith level of accounting practice)

At each level of accounting practice, some SMEs access credit some don't,

$\mathrm{n}_{\mathrm{i}}=$ those who access at ith level of accounting practice

$\mathrm{N}_{\mathrm{i}}=$ total number of SMEs at each level of accounting practice

$1-\mathrm{P}_{1}=$ represent the probability of those who do not have access to credit at ith level of accounting practice

$$
\frac{\mathrm{P}_{1}}{1-\mathrm{P}_{1}}=\text { odd ratio in favour of accessing credit }
$$


In $\left[\frac{\mathrm{P}_{1}}{1-\mathrm{P}_{1}}=\log\right.$ of the odd ratio in favour of accessing credit

$\mathrm{X}_{1}=$ ith level of accounting practice by ranking

$\mathrm{X}_{2}=$ other requirements (specifically collateral facility). This is domiciled as follows: provide collateral $=1$, does not provide collateral $=0$.

$\beta_{1}, \beta_{2}$ and $\beta_{3}$ are coefficients and $\mu_{1}$ is the stochastic error term

\section{$4 \quad$ Analyses and Interpretations}

Out of 348 questionnaires distributed, 311 were received back. This represents about $89 \%$ of the sample size. The response is summarised in the table below. 
Table 1: Accounting Practice and Fund Accessibility

\begin{tabular}{|c|c|c|}
\hline $\begin{array}{l}\text { Level of Accounting } \\
\text { Practice by ranking }\end{array}$ & $\begin{array}{l}\text { Number of SMEs Number who access funds } \\
\text { in each level of at each level of } \\
\text { Accounting }\end{array}$ & accounting \\
practice & Practice \\
$\mathrm{Xi}$ & $\mathrm{N}_{\mathrm{i}}$ & $\mathrm{n}_{\mathrm{i}}$ \\
\hline 0 & 20 & 2 \\
2 & 151 & 15 \\
3 & 83 & 21 \\
4 & 36 & 11 \\
5 & 20 & 9 \\
6 & 0 & 0 \\
7 & 1 & 0 \\
\hline
\end{tabular}

It could be seen from the above that the higher the levels of accounting practice the higher the proportion of SMEs who access loan from financiers. At 0 levels of accounting practice, $10 \%$ of the SMEs obtain loan (definitely, this must be those who are capable of providing collateral facility). We see that while $9.9 \%$ accessed fund at level 1 , $25 \%$ accessed fund at level 2. The increase continued as follows: $30 \%$ at level 3,45\% at level 4, no SME is at level 5, 100\% at level 6 and no SME at level 7. Preliminary, we assert that the higher the levels of accounting practice the higher the accessibility of fund. We are yet to confirm this preliminary result from our GLOGIT model. 


\section{Table 2: Collateral Facility and Accessibility of fund}

\begin{tabular}{lccc}
\hline $\mathrm{X}_{1}$ & $\begin{array}{c}\mathrm{n}_{1} \\
\text { Dummy }\end{array}$ & Number who provide collateral \\
\hline 0 & 2 & $2=100 \%$ & 1 \\
1 & 15 & $19=67 \%$ & 1 \\
2 & 21 & $15=71 \%$ & 1 \\
3 & 11 & $5=45 \%$ & 1 \\
4 & 9 & $0=0 \%$ & 0 \\
5 & 0 & - & \\
& - & & 0 \\
6 & 1 & $0=0 \%$ & 0 \\
7 & 0 & - & \\
\hline
\end{tabular}

As an a priori statement, the researcher is confident to ascribe 0 to any level of accounting practice if $95 \%$ and above do not provide collateral to qualify for loans otherwise it will ascribe 1. It is allowable in behavioural sciences to accommodate 5\% chances of making mistakes. The table above shows that the few SMEs at very high levels of accounting practice do not provide collateral to qualify for most loans. This is shown at levels 4 and levels 6 respectively.

Table 3: Log of the odds, Levels of Accounting Practice and Collateral Facility

\begin{tabular}{lll}
\hline $\mathrm{L}$ & $\mathrm{X}_{1}$ & \\
$\mathrm{X}_{2}$ & & 1 \\
-0.954 & 0 & 1 \\
-0.959 & 1 & 1 \\
-0.470 & 2 & 1 \\
-0.356 & 3 & 0 \\
0.629 & 4 & - \\
- & 5 & 0 \\
0 & 6 & - \\
- & 7 & \\
\hline
\end{tabular}


One interesting phenomenon is that when the log of the odds becomes 0 or positive, SMEs do not provide collateral to qualify for loans.

Table 4: Line Graph of Loan Accessibility and Relating Factors in Nigeria.

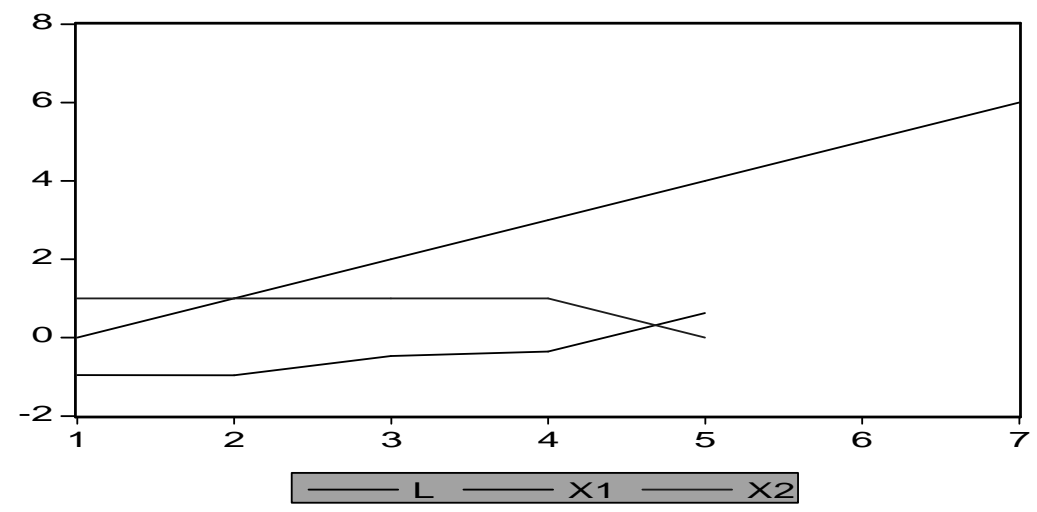

It could be seen from the line graph above that loan accessibility represented by the log of the odds (L) is rising following the rise in the levels of accounting practice $(\mathrm{X} 1)$ of the SMEs in Nigeria. We see that above the line $\left(\mathrm{X}_{2}\right)$ representing collateral facility, loan accessibility was actually rising following the rise in accounting practice. SMEs need not necessarily provide collateral facility to qualify for loans provided they maintain high accounting standard as indicated by the line X1 representing accounting standard. A further confirmation can be done from the regression results below. 


\section{Table 4: Regression Results}

Dependent Variable: $\mathrm{L}$

Method: Least Squares

Date: 12/11/12 Time: 18:13

Sample(adjusted): 17

Included observations: 6

Excluded observations: 1 after adjusting endpoints

\begin{tabular}{lcllr}
\hline \hline Variable & Coefficient & Std. Error & t-Statistic & Prob. \\
\hline \hline \multicolumn{1}{c}{ X1 } & 0.064167 & 0.045056 & 1.424147 & 0.2275 \\
X2 & -0.781000 & 0.183019 & -4.267312 & 0.0130 \\
\hline \hline R-squared & 0.747220 & Mean dependent var & -0.351667 \\
Adjusted R-squared & 0.684025 & S.D. dependent var & 0.605154 \\
S.E. of regression & 0.340167 & Akaike info criterion & 0.942441 \\
Sum squared resid & 0.462854 & Schwarz criterion & 0.873027 \\
Log likelihood & -0.827323 & F-statistic & 11.82405 \\
Durbin-Watson stat & 0.537459 & Prob(F-statistic) & 0.026327
\end{tabular}

The log of the odds ( $\mathrm{L}$ ) is positively related to the levels of accounting practice(X1). This implies that as the SMEs improve their accounting practices; their financial challenges become reduced as their access to finance increases. This is because financiers will be more willing to make fund available to them. Also following an improved accounting practice, SMEs will be more disposed to manage their funds profitably. This result is in harmony with the preliminary results shown above. The $\log$ of the odds does not have positive relationship with collateral facility(x2). We can assert that loans to SMEs in Nigeria do not necessarily depend on the ability of the SMEs to provide collateral security. However, for R-squared of 0.7472, Adjusted R-squared of 0.6840 and a significant $\mathrm{F}$ value, the two variable $\mathrm{X} 1$ and $\mathrm{X} 2$ can 
combined together to improve the financial conditions of the SMEs to a great extent.

\section{Conclusion and Recommendations}

\section{Conclusion}

The relevance of accounting information in ameliorating the financial challenges of SMEs in Nigeria has been evaluated in this paper. The researcher has conclusive evidence to assert that SMEs in Nigeria have poor accounting standard. They, therefore, generate non-informative accounting information. Further analyses reveal that SMEs' access to finance has positive relationship with its accounting practices. The higher the quality of accounting information generated by the SMEs (as shown by the designated level of accounting practice), the more access the SMEs will have to finance. We, therefore, do not accept the null hypotheses postulated in section I of this paper.

\section{Recommendations}

Based on the conclusion attained in this paper, the following recommendations are made:

- SMEs should improve their accounting system to be able to generate quality accounting information.

- SMEs should endeavour to consult accountants regularly to be able to maintain high and generally accepted accounting practices.

- SMEs should utilise accounting information in the management of their finances.

- The accounting bodies in Nigeria, the Institute of Chartered Accountants of Nigeria (ICAN) and the Association of National Accountants of Nigeria (ANAN), should wear global outfit and train their members to serve SMEs' accounting need due to their relevance in the economy.

- Accountants should be able to encourage SMEs to access their services. They should avoid scaring them away by quoting very high fees. 
- Government should stipulate minimum number of books to be kept by all SMEs that meet certain criteria which certifies them to operate in Nigeria. This dimension will be in line with international order that have designed financial reporting standard for SMEs.

\section{Reference}

Abu, N. and U. Abdullahi (2010) "Government Expenditure and Economic Growth in Nigeria, 1970-2008: Disaggregated Analysis" Business and Economic Journal, BEJ-4, 13-20.

Adelakun, T. (2008), "Why small business face high failure rates in Africa." Retrieved February 28, 2012 from http://www.helium.com/items/1019969-whysmallbusiness-facehigh-failure-rate-in-africa

AICPA (1989, 10th May), "Education member Survey", Planning and Research Division, P. 102

Aldrich, J. H. and F. Nelson (1984), Linear Probability, Logit and

Probit Models, Chicago: Sage publications

Amemiya, T. (1981), “Qualitative Response Regression Models”, Journal of Economic Literature, 19, 331-354.

Anvari, M. and V. V. Gopal (1983), “A survey of Cash Management Practices of Small Canadian Firms", American Journal of Small Business 8(2), 53-58

Anyanwu, C. M. (2002), The Role of Central Bank of Nigeria in Enterprises Financing, Seminar on "Small and Medium Scale Industries Equity Investments Scheme”, Publication No. 4, CBN Training Centre, Lagos

Aremu, M .A. and S. L. Adeyemi (2011), "Small and Medium Scale Enterprises as survival strategy for Employment Generation in Nigeria", Journal of sustainable Development, 4(1) Retrieved November 2 from www.ccsenet.org/jsd 
Aremu, M. A. (2010), Small and Medium Scale Enterprises Capacity Building in Nigeria, A paper presented at the International Conference on management and Enterprise Development on "Intellectual and New Strategies for Sustainability Development of the Third World" Held at Conference Centre, University of Ibadan, Nigeria Oct. $5^{\text {th }}-8^{\text {th }}$

Aremu, M. A. and S. L. Adeyemi (2011), "Small and Medium Scale Enterprises as Survival Strategy for Employment Generation in Nigeria", Journal of Sustainable Development, 4(1), www.ccsenet.org/jsd

Ariyo, D. (2005), "Small firms are the backbone of the Nigeria Economy”, Africa EconomicAnalysis,http://africaenomicanaliysis.org/articles/gen/ smallhtm.html. Retrieved 2012-03-27

Atkinson, J. and J. Hurstified (2003), Small Business Service, Annual Survey of Small Business: UK 2003, Brighton: Institute for Employment Studies

Banneck, G. and A. Doran (1980), "The promotion of small Business: A 7-country Study", Report prepared by Economists Advisory Group Ltd for Shell UK Ltd.Center for International Development (2012) "Entrepreneurial Finance Initiative - the Missing Middle", http://www.hks.harvard/center/cid/ Retrieved 2012-06-22

Benneth, R.J. and C. Smith (2002), "The influence of Location and Distance on the supply of Business Advice", Environment and planning A, 34: 251-70.

Blackburn, R., W. Eadson, R. Lefebore and M Gans (2006), "SMEs, Regulation and the Role of the accountants", ACCA research report No.96, London:CAET

Breen, J., T. Wilshurst and C. Calvet (2003), "Accounting Services to Small Business: the Accountant's perspective", Small business research unit, Victoria University

Carter, S. and C. Mason, (2006), "Lifting the Barriers to Growth in UK Small Business", Policy Document No 331 (UK Federation of Small Business). 
Chaston, I. and T Mangel, (2001), "The Role of Accountant in the provision of E-commerce support to small UK firms ACCA research report No.70, London: CAET

Chaston, I., B. Badger, T. Mangles and E. Sadler-Smith, (2002), "Knowledge-based services and Internet: An Investigation of Small UK Accountancy Practices", Journal of Small business and Entrepreneurship Development 9(1), 49-60.

Chittenden, F.,McConnel and C. Risner (1990), The Role of the Accountancy Profession in the Growth and Development of small business, ACCA research report No. 18, London: CEAT

CIA (2010), The World Fact book Retrieved June 6, 2011 from https://www.cia.gov/library/publication/theworldfactbook/what' s new.aspx

Cornish, C. G. (1993), Basic accounting for Small Business: Simple, Foolproof Techniques for keeping your Books Straight and Staying out of Trouble, Chicago: Self Counsel Press.

CPA Australia (2007), "Firms of the future: opportunities and challenges for public Practitioners" (Sydney: CPA, Australia)

D’Ambose, G., and Y. Gasse (1980), "Performance in Small Firms and the Utilization of Formal Management Techniques", Proceedings of the Joint National Meeting TINS/ORSA, Washington DC

Deakins, D., D. Logan, I. and Steele (2001), The financial management of the small Enterprise, ACCA research report No.64, London: CAET

DeThomas, A. R. and W. B. Fredenberger (1985), "Accounting Needs of Very Small Business”, CPA Journal 55(10), 14-23.

Devi, S.S. \& R. H. Samujh (2010), “Accountant as providers of support and Advice to SMEs in Malaysia", ACCA Research report 118.

Ebiringa, O. T. (2011), "Synthesis of literature on Small \& Medium Enterprise (SME) START-UP Finance”, International Journal on economic Research 2(1), 85-95

Encyclopaedia of Business, 2nd Ed. Retrieved October 10, 2011 from http://www.referencefrobusiness.com/small/A-

Bo/Accounting.html

Encylopedia of Business, $2^{\text {nd }}$ ed Retrieved on June 10, 2011 from http:// www. reference for business.combo/accounting.html 
Gooderham, N., A. Tobassen, E. Doving, and O Nordberg (2004), "Accountants as sources of Business advice for small firms", International Small Business Journal, 22(1):5-22.

Gorton, M. (1999), "Use of Financial Management Techniques in UKBased Small and medium sized enterprises: empirical research findings", Journal of financial management \& analysis, 12(1), 56-64.

Grablowsky, B. J. (1984), "Financial Management of Inventory", Journal of Small Business management 22(3), 59-65.

Grablowsky, B. J. and D. R. Rowell (1980), Small Business financial Management: Theory and Practice, Norfolk, Va: Dominion University

Gujarati, D. N. and D.C. Porter (2009), Basic Econometrics, New York: McGrawHill, fifth Edition

Gunu, U. (2004), "Small Scale Enterprises in Nigeria: Their Start-up, Characteristics, Sources of finance and Importance", Ilorin Journal of Business, 15 (2), 63-75.

Hans B. C. and V. N. Valeri, (2010), "Accounting-based covenants and credit Market access", JEL Classifications, M40

Huyghebeart C. \& C. Gucht (2004), "Incumbent Strategic behaviour in financial markets and exit of entrepreneurial start-ups", Strategic Management Journal 25, 669-88

Ihua, B. U. (2009), "SMEs key failure factors: A comparison between the United Kingdom and Nigeria", Journal of Social Science 18 (3), $1999-207$

Jay, L. and M. Scheper (2003), Which Advices do Micro firms use? Some Autralian Evidence, Journal of small Business and Multinationals, 2(1), 3-15

Kongolo, M. (2010), "Job Creation versus Job Shedding and the Rate of SMEs in Development", African Journal of Business, 4(11), 2288-2295

Larry, M. B. (1997) "Econometrics and Presidential Elections”, Journal of Economic Perspectives 11(3), 195-196. 
Leung, P., J. Raar and G. Tangey(2008), Accountancy services and SMEs: An Australian study, ACCA research report No.99 London:CAET

Lindecamp, D. P. and G. M. Rica (1983), "Formality in Planning and Business Success among Small Retailers", Management Forum 9(3), 126-133

Marion, S. (2009), IFRS pontra Intreprioderile Moci si Mijlocil aveantage aplicare, Diferetele intre a cest standard si IFRS Urile complete contabililatea, expertiza si audital, nr.vi, p. 29

Martin, C. (2005), Accountancy Practices and the provision of ownership succession advice, ACCA research report No. 85, London: CAET

Ministry of Commerce and Industry (2009) Field survey

Moghadden, G. and E. Hallie (2009) "Predicting the Incumbent party

vote shares in U.S Presidential Elections", Cato Journal, 29,455-468

Naomi, U. (2010, $8^{\text {th }}$ Sept.), SMEs to Issue IFRS Based financial Statements By 2014"

Nickell, G. S. and P. C. Seado (1986), "The Impact Attitudes and Experience on Small Business Computer Use", American Journal of Small Business 10(1), 57-48.

Obamuyi, T. M. (2007), “An Exploratory Study of Loan Delinquency among Small and Medium Enterprise (SMEs) in Ondo State of Nigeria”, Labour and Management Development Journal, 8, 110.

Ogujiuba, K. K., F. K. Ohuche and A. O. Adenuga (2004), "Credit Availability to small and medium scale enterprises in Nigeria: Importance of new capital base for banks- background and issues", AIAE working paper

Ohachosim, C. I. (2009), Financial Challenges of SMEs in Nigeria: Emerging Tasks for the Accountant, M.Sc. Thesis, Department of Accountancy, University of Nigeria, Enugu Campus.

Ojeka, A. and O.O. Mukoro (2011), "International Reporting Standard (IFRS) and SMEs in Nigeria: Perceptions of Academic" 
International Journal of Research in commerce \& Management, 2, (1), 13-20.

Olorunshola, J. A. (2003), "Problems and Prospects of Small and Medium Scale Industries in Nigeria", Seminar on Small and Medium Scale Industries Equity Investments Equity Scheme, Publication No. 4, CBN Training Centre, Lagos

Onugu, B.A.N. (2005), Small and Medium Enterprises (SMEs) in Nigeria: Problems and Prospects, $\mathrm{PhD}$ thesis, St. Clements University, Australia.

Osotimehin, K. O., C. A. Jegede, B. H. Akinlabi and O. T. Olayede (2012), "An Evaluation of the Challenges and Prospects of Micro and Small scale Enterprises Development in Nigeria", American International Journal of Contemporary Research, 2(4), 174-185.

Paul, P. (2009), "Direction of Standards for SMES: IFRS for SMEs" International Accounting Standards Board Review, 2, 3-5.

Potts, A. J. (1977), "A Study of the Success and Failure Rates of Small Businesses and the Use or Non-use of Accounting Information", PhD Thesis, Washington, D. C.: George Washington Uniersity.

Ram, M. and S. Carter (2001), Smaller Practices in Profile, ACCA research report No. 71, London:CAET.

Richard, G., P. Mcmahon and S. Holmes (1991), "Small Business Financial Management Practices in North America: A Literature Review", Journal of Small Business (April, 1991), 19-29.

Scott, J.M. and D. Irwin (2009), "Discouraged Advisers? The Influence of Gender, Ethnicity and education in the use of Advice and finance by UK SMEs", Environment and planning C: Government \& Policy 18(1), 5-11.

Smith, J. (1999), "Information Technology in the Small Business: Establishing the Basis for a management information system", Journal of Small Business and Entrepreneurship Development, 6(4), 326-340.

Srinivas, Y. (2005), "Bank Finance to the SME sector- Issues and Perspective" The chartered Accountant of India, 2, 336-439. 
Stiglitz, J. and A. Weiss (1981), "Credit Rationing in Markets with Imperfect Information", American Economic Review, 71, 93-40

Taiwo,A., A. M. Ayodeji and A. B. Yusuf(2012), "Impact of Small and Medium Enterprises on Economic Growth and Development", American Journal of Business and Management 1(1), 18-22.

Terungwa, A. (2012), "Risk Management and Insurance of Small and Medium Scale Enterprises (SMEs) in Nigeria", International Journal of Finance and Accounting, 1(1), 8-17.

Thomas, J. and R. V. Evason (1987), "An Empirical Investigation of Association Between Financial Ratio Use and Small Business Success", Journal of Business Finance and Accounting 14(4), 555-571.

Udechukwu, F.N. (2003), "Survey of Small and Medium Scale Industries and their Potentials in Nigeria", Seminar on Small and Medium Industries Equity Investments Scheme, publication No. 4, CBN training centre, Lagos

Watson, J. (2003), "The potential impact of accessing advice on SME failure rates", seminar paper, $16^{\text {th }}$ annual conference of Small Enterprises Association of Australia and New Zealand

Yusoff, N.M.H. (2006), "Supporting the Development of SMEs, Bridging the Services Gap", Accountants Today, 19(8) 12-14 